\title{
DECISION-MAKING METHODOLOGY BETWEEN REVITALISATION AND REHABILITATION OF WORLD HERITAGE CITY CENTERS. CASE STUDY: THE ANCIENT CITY OF ALEPPO (SYRIA)
}

\author{
S. Ibrahim ${ }^{1, *}$ \\ ${ }^{1}$ Marcel Breuer Doctoral School, Faculty of Engineering and Information Technology, University of Pécs, Boszorkány u. 2, H-7624 \\ Pécs, Hungary - Sonia.eb.arch@gmail.com
}

Commission II - WG II/8

KEYWORDS: World heritage cities in danger, Syrian Heritage, Post-conflict rehabilitation, Documentation, Drone.

\begin{abstract}
:
The ancient city of Aleppo is one of the oldest continuously inhabited cities in the world. It may have been inhabited in the sixth millennium BC and it is a World Heritage City since 1986. Aleppo was severely damaged during the Syrian conflict. Therefore, the paper explores the adequate frameworks that are needed to tackle the emerging challenges of conservation in complicated situation after conflicts. As any conservation action starts with a decision, conservation standers adopted since the early twentieth century acknowledge the need for decisions to be informed through the best available scientific evidence. This paper proposes an analysis of the methodology used for the evaluation of damages caused by war in Aleppo and suggests decision-making tools DMT validated through a pilot project to guide post-conflict revitalization efforts. Within this framework, this paper analyzed the DMT in the rehabilitation of a Souk in the historic commercial center as the pilot project implementation. The project was done by 'Aga Khan Foundation' in partnership with 'Directorate General of antiquities and museums' in Syria and different national stakeholders. The success of the pilot project within the expected timeframe, materials, cost, and the souk regaining its function and vitality was recognized as a validation of the credibility and validity of the methodology adopted. The resulted data (plans, $3 \mathrm{~d}$ scanning, etc.) are tools for decision-makers in the field of rehabilitation. The methodology can be replicated by all actors in the fields of conservation, whether in Aleppo or any other historical site.
\end{abstract}

\section{RESEARCH BACKGROUND}

The destruction of cultural heritage does not damage only communities; it also threatens longstanding peace around the world (UNESCO, 2010). In cities stroked by armed conflict, the fabric of human society seems increasingly under attack by forces that deny the existence of the shared heritage. However, the world heritage holds out a contrary and positive vision of human nature (Train, 2002). After witnessing the scale, persistence, and nature of destructive events of recent times, heritage cities have become the battlefields (Graham, 2009), and have been radically reshaped through the destruction of their social, cultural and built environments (Grodach, 2002). In Syria, ancient cities, ancient citadels, heritage sites, etc. were used as battlefields (Ali, 2016). Syria has six properties inscribed on the world heritage list. They were damaged during the war and inscribed on the list of WH in danger (UNESCO, 2013). The paper investigated and analysed the reports published by different organizations (DGAM, AAAS, UNESCO, UNITAR, ASOR) to reach the percentage of damages of cultural heritage in Syria. As a result, Figure 1 shows the percentage of damage in historical cities in Syria, Aleppo has the highest percentage with $31 \%$ of the damaged heritage. More than $60 \%$ of the ancient city is damaged (UNESCO/UNITAR, 2018). Such loss of heritage is due to three different factors: looting, deliberate targeting, and the use of heritage sites for combat purposes. The devastated alleys of the ancient Souk (historic commercial center) of Aleppo are an example of the latter category (De Cesari, 2015). However, the current dilemma regarding the situation in Aleppo is "abandoned" because even after three years of announcing the city free from fighting (Sim, 2016), Aleppo is still uninhabited. People cannot go back and rehabilitate their buildings due to the lack of strategies for recovery and reconstruction.

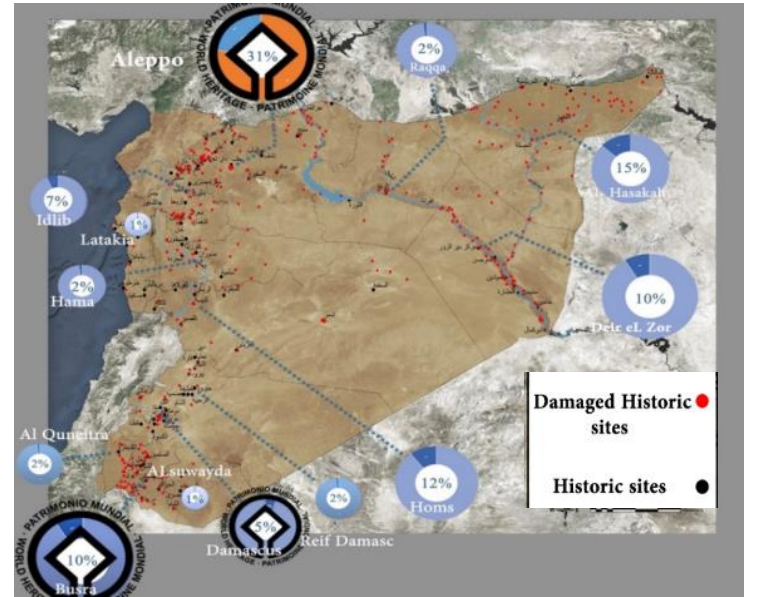

Figure 1. Syria map, Percentage of damage, source: S. Ibrahim.

Therefore, one of the oldest continuously inhabited cities in the world is still without its inhabitants. The ancient city of Aleppo is a world heritage city WHC since 1986, and it is another example of severe destruction (Sabloff, 2008). It is located at the crossroads of several trade routes that have been active since the second millennium $\mathrm{BC}$ and were ruled by different great civilizations, all of which influenced the architecture of the city. Aleppo is inscribed based on its "outstanding universal values" (OUV); two criteria were considered, /III/: includes the idea that the old city of Aleppo reflects the rich cultures of its successive occupants and /IV/: that Aleppo is a prominent example of a city from the 12th century Ayyubid Era (UNESCO, 2019). Since inscription, the features of the ancient city surrounding the citadel

\footnotetext{
* Corresponding autor
} 
overlooking it, did not change until the outbreak of the Syrian conflict in Aleppo in 2012. The city was subjected to massive destruction as a result of the war, and UNESCO in its joint report with UNITAR, showed that $10 \%$ of the buildings of the Old City is destroyed, and $51 \%$ is moderately damaged (UNESCO/UNITAR, 2018), as shown in Figure 2.

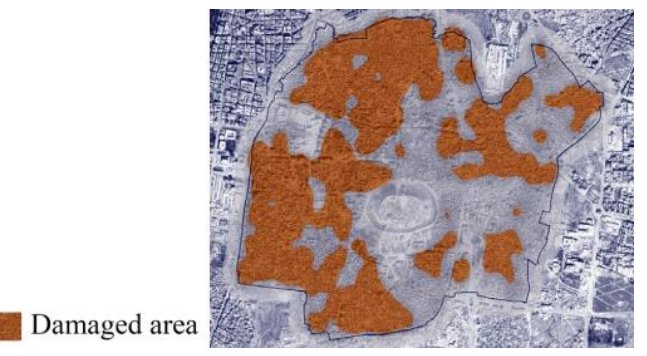

Figure 2. Ancient City of Aleppo, destruction overview 2017 (C) UNESCO/UNITAR, (2019)

The paper presents the first step of much comprehensive research to propose a guideline for the revitalization of WHCs. The paper analyzed a methodology in documentation and a potential pilot project that were implemented in 2019 and resulted in the rehabilitation of Al-Saqatiyya souk (ancient market) in the historic commercial center of Aleppo. This souk was chosen to be an empirical study as a Pilot project. The objective of the methodology was to be replicated and implemented in the rest of the damaged urban fabric. However, while such a project is undoubtedly well-intentioned, it occurred within a complex (post) conflict environment, in which the IS and many other actors remain capable of unleashing new waves of missile attacks and it was important for this project to break the anarchy of a postconflict situation and to create a prototype that will both boost the morale and set up a standard to continue restoration of the Old City (Monreal, 2019). The project was implemented by the Aga Khan Trust for culture (Syria) AKTC which focuses on the physical, social, cultural, and economic revitalization of communities in the developing world. It is one of the agencies of the Aga Khan Development Network (AKDN) operating in thirty countries around the world including Syria (AKDN, 2018a). The AKTC cooperated with the Directorate General of Antiquities and Museums (DGAM) since 2000 in the restoration of three famous castles, and the restoration of several historic houses in Damascus. The Cooperation continued to this day, and the last one was the rehabilitation of the historic commercial center of the ancient city of Aleppo (AKDN, 2018b). The restoration of the ancient city to regain its historical, economic, and cultural values was the aim that led the AKTC to intervene and try to revive this still-endangered cultural heritage in Aleppo (Esmaiel, 2019). However, in abandoned, deserted, and heavily destroyed cities, revitalization is the key planning procedure to rebuild the social and economic activities of a historic site or city which has lost its original function and vitality as a consequence of war (Feilden and Jokilehto, 1998). Considering that WHCs are recognized for their OUVs, it is crucial to guarantee that their authenticity and cultural values are appropriately preserved (ICOMOS, 2017). In addition, rehabilitation means the physical improvements that are necessary to provide an appropriate use to an empty or inappropriately utilized structure (Feilden and Jokilehto, 1998), and it is one of the main procedures that specialists do to maintain the OUV and revive the WHCs. However, rehabilitation in WHCs after conflicts necessitates significant preparatory methodologies in systematic and theoretic stimulating ways. It demands specific tools, which should be used to validate the revitalization of the urban context and guarantee accurate documentation (Feilden and Jokilehto, 1998). In a context where most of the efforts are dedicated to medical care, food and shelter, heritage is always ignored and decisions become more challenging because time is tight, resources are insufficient, and public pressure is high, all of that increases vulnerability to make the right conservation decisions (StanleyPrice, 2005). Therefore, the paper presents a pilot project implementation as a validation to decision-making tools. Those tools will support future development for a master plan of revitalization, defined by objectives of recovery and rehabilitation and re-establishing OUV attributes and community participation.

\subsection{Research workflow:}

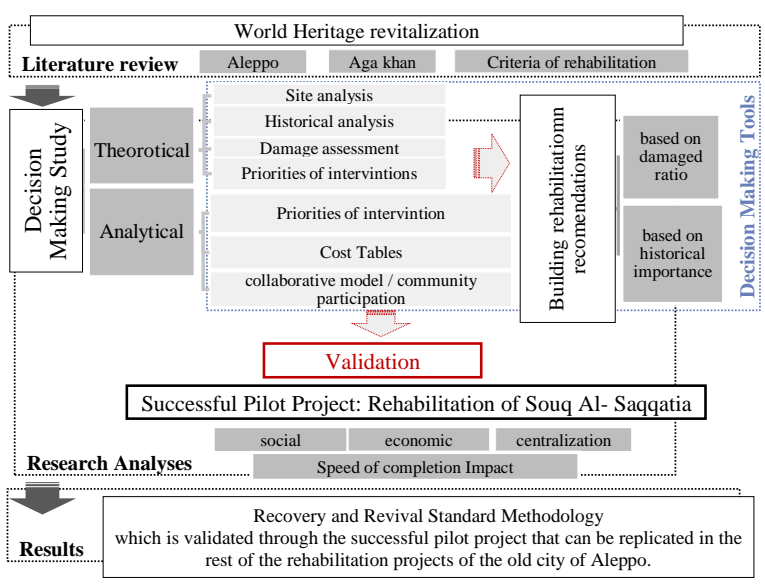

Table 1. Research structure.

\subsection{Objectives of the research}

1. The Standard Methodology in revitalization after conflicts.

2. A pilot project as a validation.

\section{THE STANDARD METHODOLOGY}

The methodological study includes analytical and theoretical studies. The importance of the theoretical and analytical study lies in the fact that it concluded with the preparation of a model / standard methodology that could be replicated in projects to revive the rest of the ancient city. Then this model was followed with an applied study (the implementation of a prototype project).

\subsection{Theoretical and Analytical study}

The theoretical and analytical study aimed to prepare existing situation assessment and plans to identify the site, including:

1. Community participation and multiple stakeholders' collaborative model.

2. Site analyses and documentation: (2D and $3 \mathrm{D}$ scanning)

3. Historic Development Plans.

4. Damage Assessment plans (damage scale and type).

5. Cost Tables: specifies the expected costs of any rehabilitation project to be implemented in every sample (zone) in the future.

6. Priorities of intervention (plans and recommendations)

\subsection{Applied study (A prototype process implementation)}

The analytical and theoretical study was followed with an empirical study through the implementation of a pilot project. Which is the rehabilitation of Al Saqatiyya Souk in the historic commercial center of Aleppo. The study will serve as a contribution to help decision-makers in urban and spatial planning and city professionals make restoration, rehabilitation decisions to reach the recovery and development of Aleppo. 


\section{THE PROJECT}

\subsection{The theoretical study phase (analytical- documentary)}

\subsubsection{Stakeholders and community participation:} Understanding the interpenetration of tangible and intangible aspects of cultural heritage, especially in inhabited post-conflict cultural environments, underlines the necessity for a new mindset, one that perceives reconstruction as a set of processes, with a high priority placed on sustainable development and active engagement of communities. Such considerations must underpin any framework for recovery and reconstruction (ICOMOS, 2017). The social element is the most important, as revitalization is not only about the physical buildings, it is also about bringing people back together, recreating a sense of community and belonging. Postconflict decisions need to be made to construct a narrative that is not only historically reliable but also of interest to the community and takes into consideration the challenge of people's engagement. In the post-conflict situation in Syria, governing bodies have limited capacity and authority, and communities are displaced or sometimes replaced by populations without specific cultural links to the place. Therefore, the importance of community participation and different stakeholders was emphasized in the project. In 2017, AKTC coordinated with international (UNESCO) and national institutions, organizations, and governmental parties which are Directorate General of Antiquities and Museums, Directorate of the Old City of Aleppo, Heritage Committee in Syria, Engineers Association of Aleppo, Faculty of Architecture-Aleppo University and El Adiyat Association in Aleppo (DGAM, 2017) to achieve participation by identifying ways to demonstrate the socioeconomic benefits from rehabilitating the Souk and its role in accomplishing the sustainable development goals in the city. Different stakeholders participated in several different interest groups to impact conservation decisions. In 2018, initial consultation with stakeholders at the micro, meso, and macro levels (e.g. community members, shop owners, and policymakers) was done. The next step was qualifying local labor, to involve the local communities' forces in the restoration work, training courses in stone restoration techniques and documentation by international experts has been organized. Youth groups from Aleppo were created called "Subhuyyat" "صبحيات" by AKTC, and different meetings were done for consultations that continued for nine months. Meetings included art and cultural events or seminars, classes, or workshops (AKDN, 2018c). The goal was to prioritize intervention according to local opinion and prepare local expertise capable of participating in the restoration process. A "Souk Committee" "لجنة السوق" was created from head shop owners as communication channel between the Aga Khan and shop owners, to understand their real estate situation, commercial activities, their usage of the souk corridor, their shop rehabilitation opinions and expectations about the process, in addition to a social survey that required all shop owners answer questions about requirements, needs, usage of the shop and the Souk. The social survey had a group of 35 questions (public services required, entrances, necessary equipment, etc.). Then an analysis of the collected data has been done to prioritize intervention options. NGOs and different administration were involved during the work like DGAM (Directorate general of antiquities and museums) who supervise conservation tasks in the ancient city projects, the municipality, the Governorate, Ministry of Tourism and the Syria Trust for Development which is an NGO that helped some shop owners in rehabilitating the shops interior (Syria Trust For Development, 2020). The restoration work of the project was implemented by local contractors and workers. The coordination was done by AKTC between various stakeholders as a true participatory among all groups of society, that represents a publicprivet, governmental- administrative (national- local), privet
(NGO) and community (decision-makers- operators of the markets- customers- people in the street) partnership. Coordination aimed to achieve participation and accomplish sustainable development goals in the war-torn city.

3.1.2 In addition to the social and collaborative model, the study aimed to reach a convenient, clear, understandable, precise, and repeatable methodology by analyzing and assessing three different study samples (zones) in the city, as shown in Figure 3.

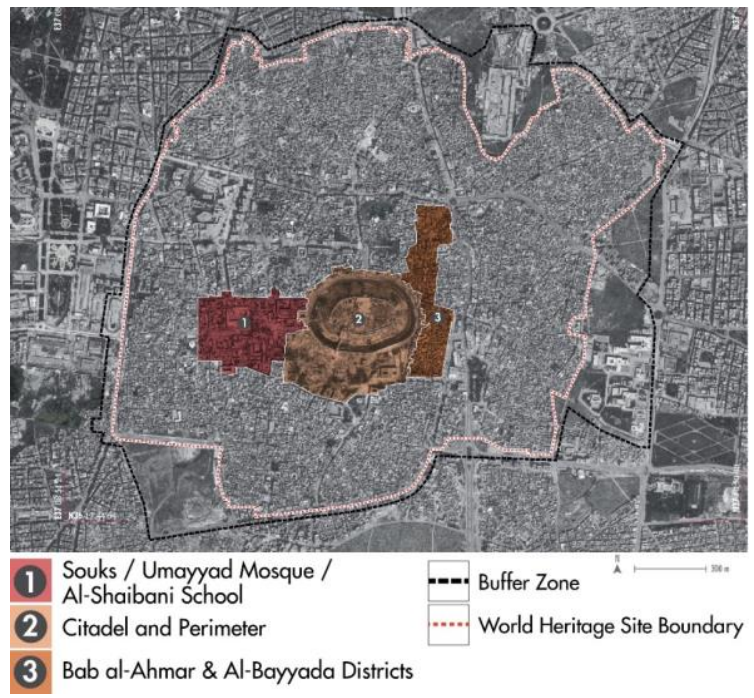

Figure 3. Aleppo map and the studied zones @AKTC (2019).

The first Zone: Historic Souk area/ commercial centre, the Umayyad Mosque and Al-Shaibania School, (the commercial and service sectors zone- the Umayyad Mosque neighborhood). The second Zone: Aleppo Citadel and its surroundings, (the tourist attraction sector). The third area: $\mathrm{Bab} \mathrm{Al}-\mathrm{Ahmar}$ and $\mathrm{Al}-$ Bayyadah, (Residential sector). These three zones were chosen because they contain various functions of buildings, including commercial, religious, social, or residential functions, and each one was considered as a model that can be replicated. Fieldwork began after the selection of samples, and the first task was to achieve a thorough, comprehensive, and accurate damage assessment of the buildings in the three zones through:

1. Dividing the entire study area that includes the three zones into identical frames and coding them to facilitate the documentation and analyses process of the existing situation, shown in Figure 4.

2. Taking pictures with high resolution: In this phase, in addition to the field documentation groups, a drone was used to capture high-resolution aerial images of the studied zones; 3181192 pictures were taken in just ten days. Figure 5 shows the selection of image frames from shooting points and Figure 6 a visualization of shooting points and frames from the drone- operated camera.

3. Image processing to achieve three- dimensional documentation of the three zones, using deferent software (AutoCAD, Photo scan, Recap, etc.), Figure 7 shows section and site plan of Saqatiyya Souk from zone (1) as an example of the result from the 3D documentation and analysis.

4. Analysis of documented zones (1-2-3), the 3D documentation was an accurate tool for identifying and documenting debris, assessing structures, and preparing a complete zone survey and assessment. Figure 8. Shows a section and site plan of the Great Omayyad mosque from zone (1), the debris of the destroyed minaret are clearly apparent, measurable, and identified. 


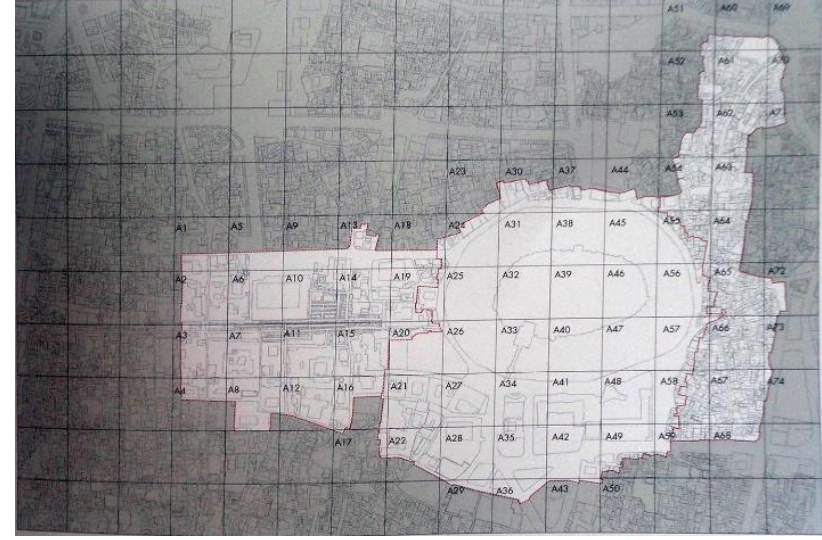

Figure 4. Defined areas within a grid, (AKTC (2019).

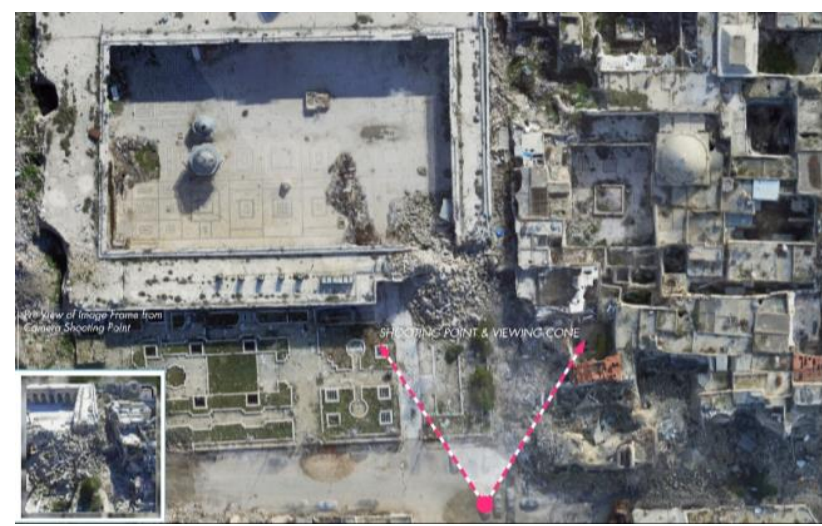

Figure 5. Shooting point and viewing cone @AKTC (2019).
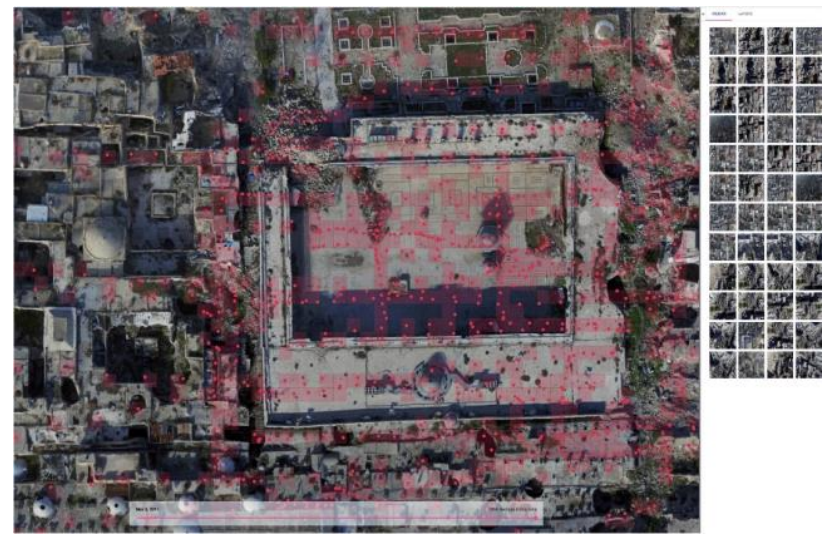

Figure 6. The red points represent the drone's shooting points, data source for damage assessment (ICONEM platform), CAKTC (2019).

The three-dimensional models are useful tools for documenting historical monuments and sites. They can be used as a means of scientific research or to preserve the memory of the site, or to achieve access- digitally or in print - to a physical structure that cannot be seen otherwise. In addition, 3D models provide a starting point for decision-makers to plan the recovery of heritage buildings or neighborhoods (DAI, 2019). As virtual models, they can be shared globally via the Internet, easily stored digitally, or printed using a $3 \mathrm{D}$ printer. With this resulting physical structure, we obtain information such as the sections or the site plan, the size, and type of debris that could be used in rebuilding especially in highresolution images. Through these drawings, we can prepare detailed projects such as in our case studies.

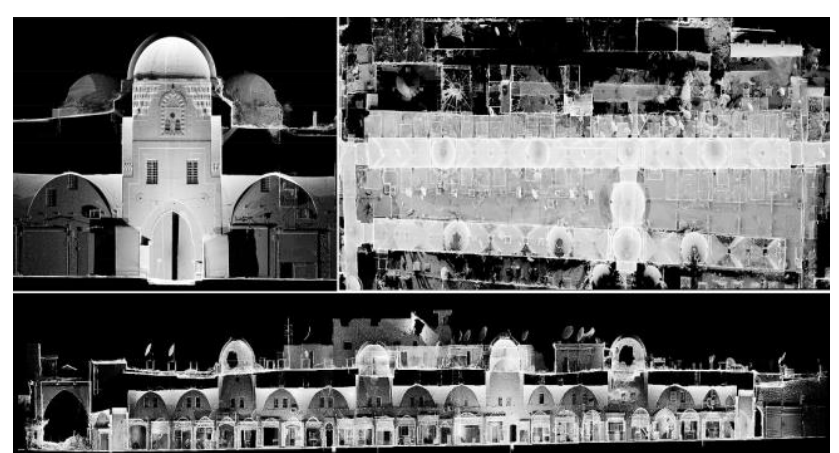

Figure 7. Souk Al- Saqatiyya sections and site plan (C)Bruno Deslandes.

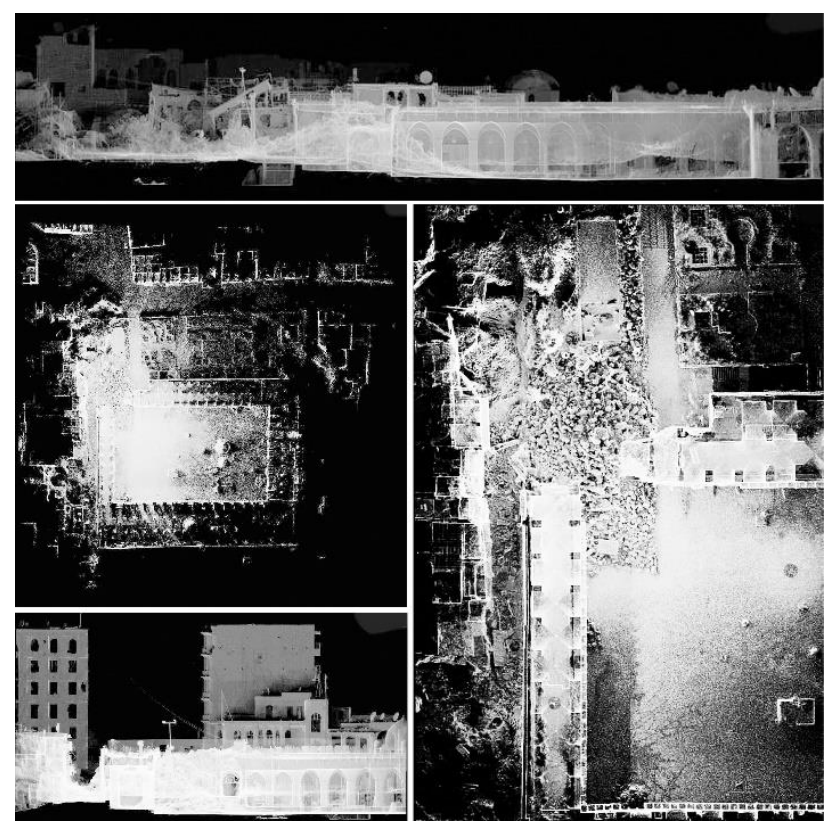

Figure 8. The Great Omayyad mosque 3D analyses, the debris of the destroyed minaret (right) and section and site plan (left) (CBruno Deslandes.

5. The analysis of high-resolution aerial photos was taken by the drone. Figure 9 and Figure 10 shows the analysis for the aerial photo of sector A6 and its usage in assessing and documenting the damage (AKTC, 2019).

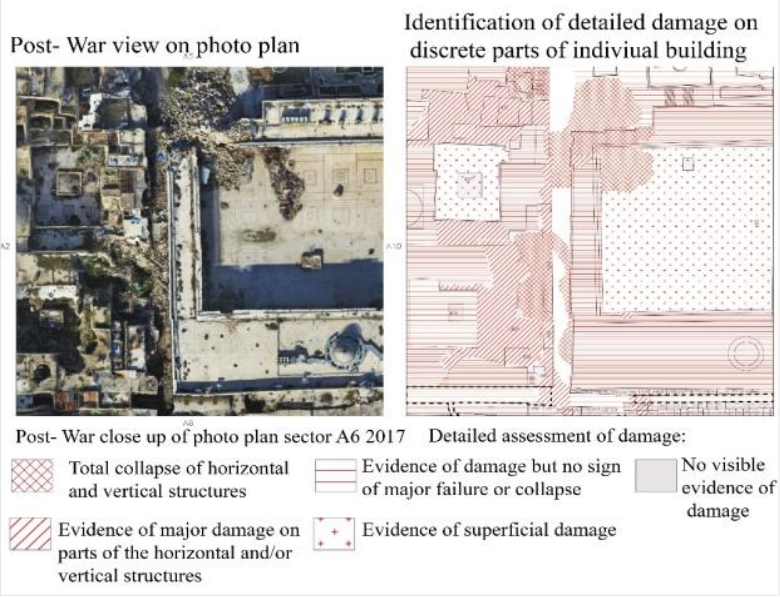

Figure 9. A detailed assessment of damage @AKTC (2019). 


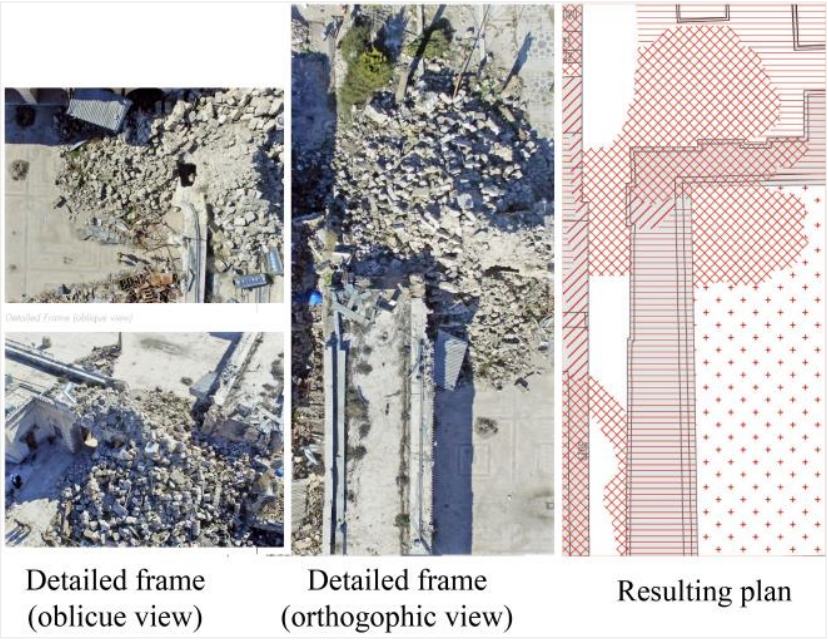

Figure 10. Visualisation of Frames for Detailed Assessment of Damage @AKTC (2019).

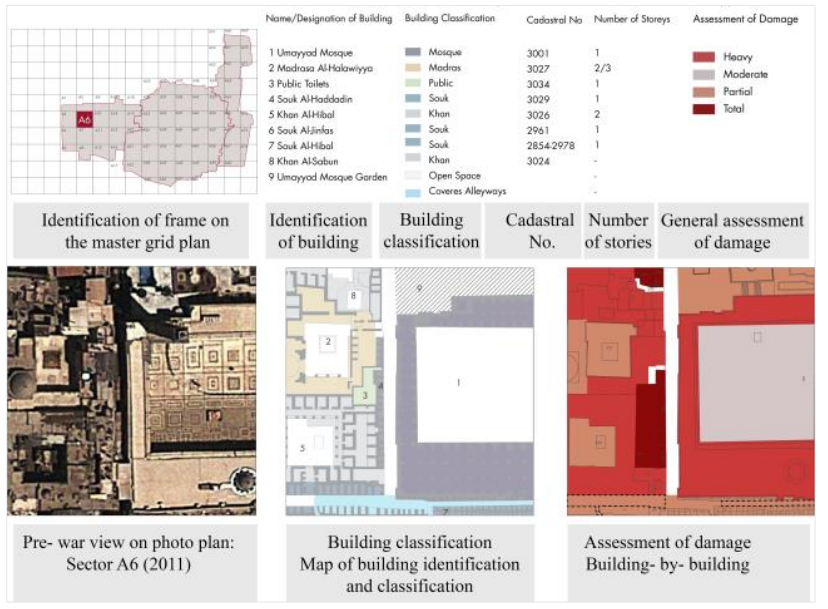

Figure 11. FRAME A6: Components of the standard assessment form number (1), (CAKTC (2019).

6. The analytical steps were repeated on each sector to reach high-resolution architectural documentation and analysis, based on this, the detailed plans of the three zones can be done with limited error rates. The analytical steps consist of the identification and indexing of buildings from the city's cadastral plan of the three zones. Figure 11 illustrates the methodology of the work done on the sector (A6) for analyzing and assessing.

7. The number and classification are identified to simplify the documentation and then the damage assessment is stated with the corresponding image. This analysis resulted in "the standard assessment form (1)", shown in Figure 11 which consists of detailed information that is assessing and comparing the current situation with the pre-war documentation.

\section{Components of the standard assessment forms:}

They consist of information about:

1. Identification of the frame on the master grid plan.

2. Identification of building, (Name/Designation of the building).

4. Building classification.

5. The administration number (Cadastral number).

6 . The number of levels.
7. Assessment of damage. (Heavy- Moderate- Partial- Total).

8. Pre-war view on photo plan.

9. Map of Building classification.

10. Plan of damage assessment building by building.

11. Post-war view on photo plan.

12. Identification of detailed damage on discrete parts of the individual building.

Moreover, the standard assessment form (2) consists of closeups of the frame with the identification of damages and debris through high- resolution close-ups, shown in Figure 12.

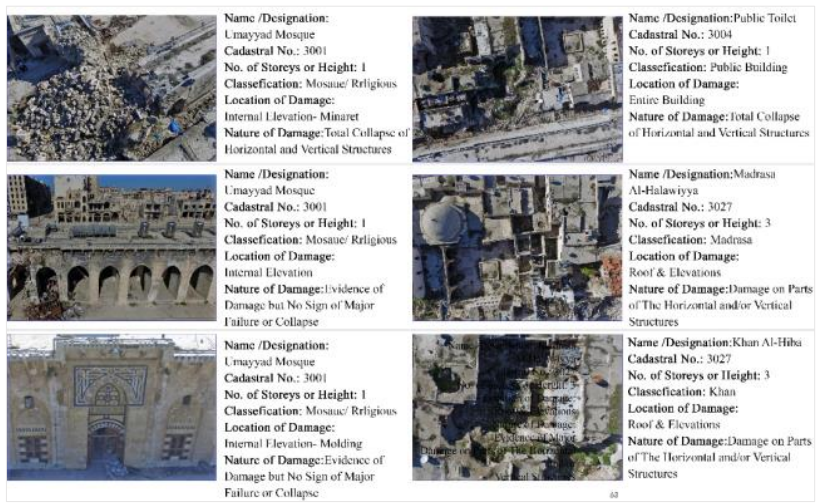

Figure 12. Standard assessment form (2), @AKTC (2019).

\subsubsection{Tools for decision-makers}

To obtain a simple, clear, flexible, and practical tool to facilitate the decisions of conservation, the previous assessment resulted in different plans as decision-making tools, Figure 13, Figure 14:

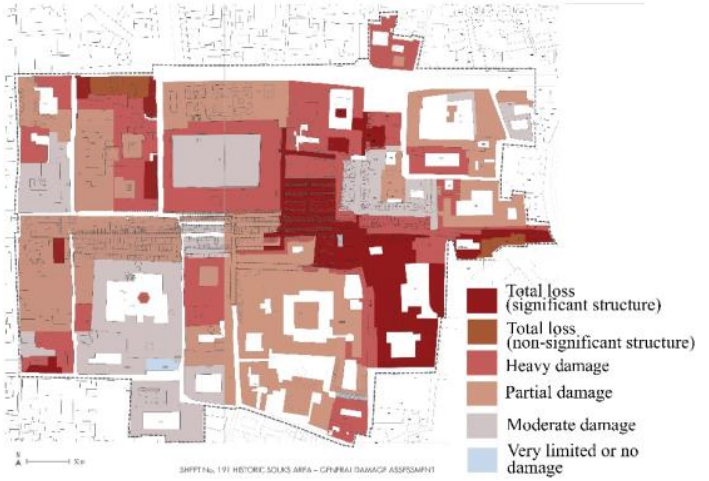

Figure 13. Historic souk area- General Damage assessment for zone (1), @AKTC (2019).

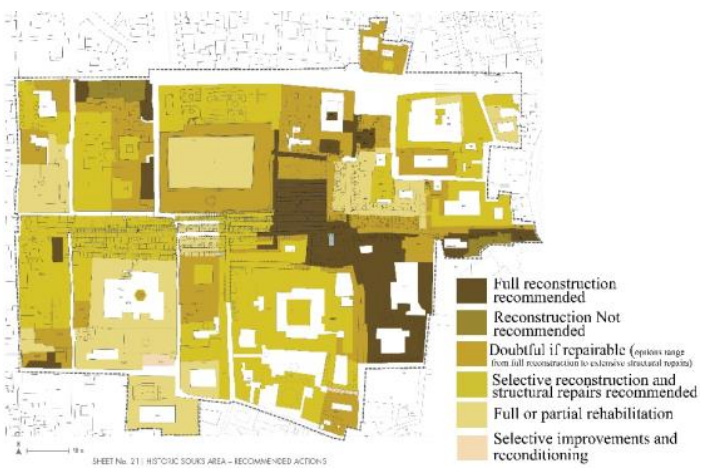

Figure 14. Recommended actions, prioritizing of intervention based on the damage ratio for the zone (1), @AKTC (2019). 
1. General damage analysis plan.

2. Detailed damage analysis plan.

3. Outline and plans of the intervention priorities based on the proportion of damage.

4. Outline priorities for intervention based on historical significance (AKTC, 2019).

The previous plans provided an overview of the scale of damage and the priorities of the intervention. However, to obtain more accurate results, it was necessary to reach accurate numbers regarding damage and percentage of damage and the number of buildings affected. Therefore, to make the methodology more realistic and feasible, tables and statistics were created for number of buildings affected, according to their area, function, number, and rates of damage, an example of zone (1) Figure 15 shows rehabilitation recommendation based on Area by building type and damage levels, Figure 16 shows rehabilitation recommendation based on analysing numbers of buildings by type and damage levels and Figure 17 shows rehabilitation recommendation based on the percentage of total Area by building type and damage levels.

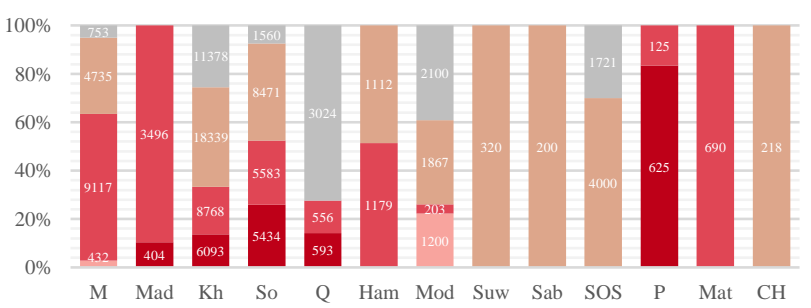

Figure 15. Rehabilitation recommendation @AKTC (2019).

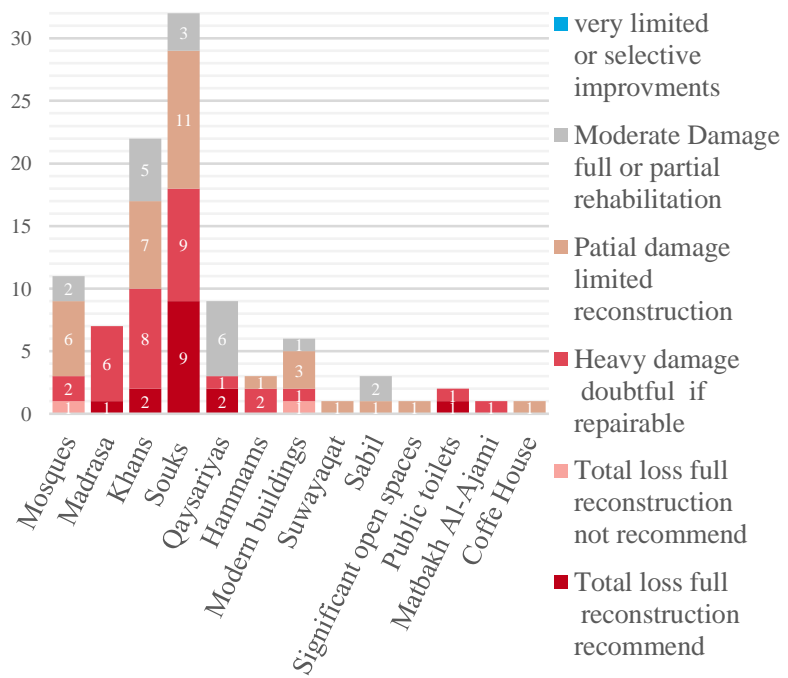

Figure 16. Rehabilitation recommendation @AKTC (2019).

The statistics provided a decision-making tool as it shows recommendations for rehabilitation based on comparing different criteria (damage- area- function) that were concluded from the theoretical analytical approach. The predicted cost statistics and numbers were determined by comparison with "the windmill tower of Aleppo citadel project" in 2017, which was implemented by the Aga Khan Foundation. The windmill project cost amounts and tables included prices of materials and implementation techniques since the cost of used materials and techniques of the different tasks are similar in the historical City projects, Therefore, based on the project cost amounts and by generalizing the costs of the windmill project on cadastral area proportions, the predicted costs for the rehabilitation projects of the three zones from the old city were calculated. The resulting cost tables are one of the rehabilitation decision-making tools in the methodology. The importance of this decision-making tool is that it can be used to calculate the cost of all future rehabilitation works in the Old City, based on damage assessment plans and intervention priorities. The decision-making tools were featured as rehabilitation recommendations, the recommendation was based on different values like priorities of interventions based on historical importance or level of damage. The tools are clear and depending on the chosen values of the stakeholder and the rehabilitation decision could be taken easily. Consequently, the conservation decisions in rehabilitation projects depend on analysing and assessing the existing situation, which benefits in prioritizing interventions. Each of the previously described plans presented one of the tools to make the decisions. In addition to the theoretical and analytical study in 3.1 that also covered the historical development of the site and the classification etc. The accuracy and the impact of the decisions depend on the described high-resolution documentation, the methodology resulted in a standard model for analysing the damage and prioritising interventions. It is a very helpful methodology in decision making in the next phase, which is the creating of the detailed project (conservation actions) for the rehabilitation and revitalization.

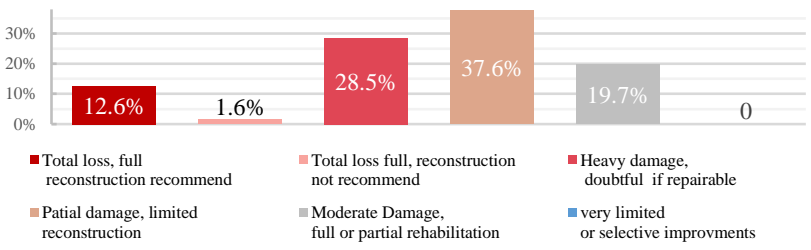

Figure 17. Rehabilitation recommendation @AKTC (2019).

\subsection{Applied study phase: Reviving part of the Historical City "Souk Al-Saqatiyya":}

The verification of the methodology was done by implementing the pilot project. The selection process of the function and location from the three zones began with criteria based on the AKDN methodology that stimulates social, economic and cultural development (AKDN, 2018a) and started from reflecting on local community urgent and long term needs, social, economic, and cultural which are invisible dynamics that shape the urban environment. The socioeconomic dynamic was the main criterion in the context-dependent decision making because it has the main influence on regaining the vitality of the city (Monreal, 2019). That confirms that it is essential to see heritage as a means of development, not just as an object of pride. Therefore, historic commercial centers or "Souks" are the main building functions that can influence the three criteria, as follow:

1. The economic criterion is linked with the fact that the ancient souks are popular and folk markets, so the customers are mostly low-income. Commercial activities are related to the sale of daily products. Merchants, shop owners are from different social class backgrounds, from the city, suburbs, and countryside (Al-Jibai, Shakeeb, 2016), which ensures the souk activation after the restoration and the return of commercial traffic to it.

2. Historical Souks were not merely places of commerce; they were social, cultural, and interactive centers of meeting, dialogue, discussion, and social interaction for people of Aleppo In addition to the significant impact of restoring the historic commercial center on the future of the city and turning the rehabilitated Souk into a glimmer of hope that will pave the way for the comprehensive revitalization which is a significant challenge given the magnitude of the massive 
destruction (ALFA, 2015). After determining the function which is a "souk" it was necessary to determine which Souk to be rehabilitated, therefore, two criteria were considered:

3. Basic connection knot: the Souk should be a central connection link in the urban fabric of the historic center, which means the market occupies a position that connects different Souks as shown in Figure 19, the location of AlSaqatiyy Souk.

4. Achievement in a record or Typical time, any project in complex (post-) conflict environment should serve people as quickly as possible, which is necessary because of its impact on the public and community opinion, therefore, a market with less damage should be selected.

After using the decision-making D.M tools to determine which souk meets the standards, Souk Al-Saqatiyya was chosen. Plans of general damage assessment of zone (1) were used to determine that Souk Al-Saqatiyya presented evidence of major damage but no sign of major collapse as shown in Figure 13, and Figure 18 shows the recommendations and the choosing prosses.

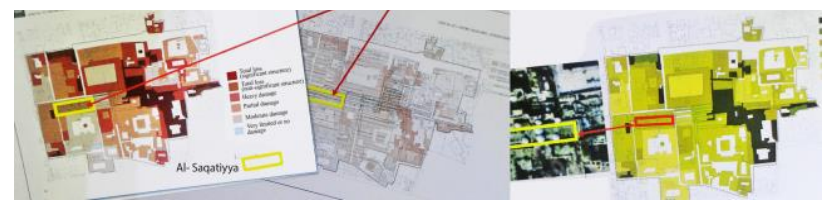

Figure 18. D.M tools @AKTC (2019).

3.2.1 Souk Al-Saqatiyya rehabilitation: Aleppo was a commercial and populated city, its Souks were considered the biggest covered historical Souks in the world as the length of its covered markets reached $12 \mathrm{~km}$ and 16 hectares area, 119 Souks with 6000 shops in the early twentieth century (Al-Jibai and Shakeeb, 2016). In addition to the location that historically has provided the potential of becoming an important commercial and invention center since its foundation. The reconstitution studies showed that the commercial center has retained its location since the Hellenistic period in the 3rd century B.C. Souk Al-Saqatiyya occupies the center of the main axis of "Souk Al-Madina" the commercial core of Aleppo that consisted of over a square kilometer of interlocking streets, filled with shops, workshops, mosques, baths, and khans, all under one contiguous roof that attracts the residents of the city and the countryside from all parts of Aleppo (Al-Ghazzi, 1992) (Raymond, 1984). Souk AlSaqatiyya was mentioned in Khair al-Din al-Asadi book "Neighborhoods and Souks of Aleppo" as one of the most prosperous Souks of the historical city (Al-Din al-Asadi, 1984). Its architectural composition is considered one of the most impressive markets as a witness to the durability and stability of the city of stones. It is also considered as a model of Aleppo's markets in the Ottoman era and the most prominent characteristics of Islamic architecture. The Souk extends east-west, with a length of $113 \mathrm{~m}$ and corridor width ranging between (4.7- $4.9 \mathrm{~m}$ ) and fifty-three stores of various specialties are distributed on its sides, the shop area is between $\left(18.9 \mathrm{~m}^{2}-7.9 \mathrm{~m}^{2}\right)$, the storefronts along with this axis form a continuous strip and they occupy almost the entire facade of the street. These facades are characterized by their semicircular arches and groined vaults contract at the ends of the roof to separate the market from its neighborhood (David et al., 1998) (Gaube and Wirth, 1984). There are four domes each one has a circular plan and is based on a pedestal that forms a polygon, still maintain their original building material (brick-roasted brick). The stores sell Spices, pistachios and grains, meats, food, vegetables, and some of them are restaurants. The nature of the jobs and smells was different in Al-Saqatiyya market before the war, the Souk formed an old restaurant in the center of the old city, close to the Khans, where travelers and foreigners reside, see Figure 20.
The recommended actions were to implement selective reconstruction, structural repairs, and general rehabilitation as $34 \%$ was damaged of the Souk, and after gathering building data and preliminary damage review there were recurrent dilapidation issues at various locations from damaged or missing stones, wood gates in need of restoration, dilapidated decorative stonework, missing mortar joints, damaged domes and inoperable or damaged metal rolling shutters in addition to developing the services in the Souk (lighting, solar panels, etc.), the boundary of intervention area are shown in Figure 19. The project was done in seven and a half months which is a typical period considering the location, conditions, and work tasks. The Souq corridor with 53 shops were rehabilitated, the details and conservation actions were prepared and implemented within the expected timeframe and material costs. The success of the project within the expected timeframe, materials, cost, and the souk regaining its function and vitality, is a validation of the credibility of the methodology.

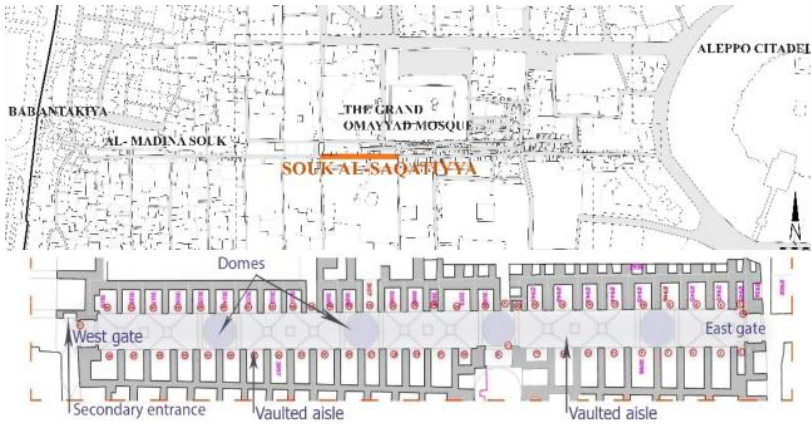

Figure 19. Al-Saqatiyya Souk location and Plan, S. Ibrahim.

\section{CONCLUSIONS}

In post-conflict WHCs the reconstruction process needs to find a balance between preservation and development. A revitalization approach to create the connection and transition point between relief phase and post-conflict development phase, therefore, it is important to reactivate projects that have a direct instantaneous impact to improve people's lives, and in the same time have a gradual development criterion. The methodology of the theoretical and analytical study could be replicated or reused by all actors in the fields of conservation and rehabilitation of historical sites in post-conflict environments, and the plans and documentation are tools to help make conservation decisions in rehabilitation projects.

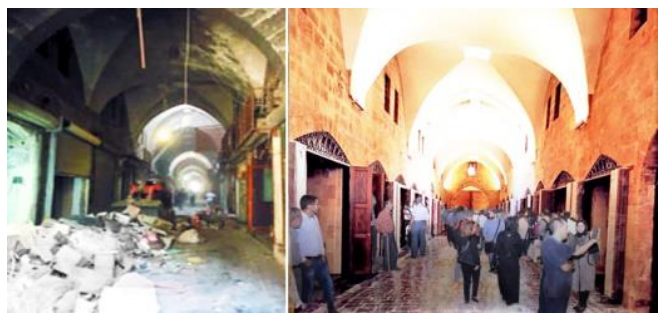

Figure 20. Souk Al- Saqatiyya 2016 - 2020, S. Ibrahim.

- To implement the methodology, initially the targeted area is defined based on a set of criteria and the objectives of the rehabilitation process. The plans, damage rates, estimated costs and predicted duration provides an accurate and predictable timeline for the project, determining the required quantities of materials (stone, mortar ...), the cost of these materials, the expected time of work and the necessary human resources, those are the decision-making tools. The documentation of the project phases is essential to achieve replication. 


\begin{abstract}
- The challenge is to engage with local NGOs and the local communities and authorities, to give their voice a place in the question of rebuilding. Therefore, the methodology set community participation and multiple stakeholders' collaborative model that shows potential opportunities in revitalization projects to give a sense of hope, belonging, and ownership for people in their city. The model promises a notable potential in engaging communities. However, further research should be conducted with surveys and statistics, interviews, and questionnaires regarding community reaction to the project, to improve this collaborative model.

- D.M tools help to revive the historical city effectively so it will regain its vitality and OUV in a limited and controlled period.

- Documentation must be conducted with an idea to improve management, and it is crucial to develop a documentation system for documenting the management and the project (the paper detailed the documentation as a reference for future projects).

- Strategies created by practical decision-making tools play a significant role in revitalizing the damaged post-war heritage.

- Conservation is a great platform for interdisciplinarity projects and post-conflict decisions need to be made regarding function, vitality, public participation, and engagement as main aims.
\end{abstract}

\section{ACKNOWLEDGEMENTS}

The author would like to thank the Tempus Public Foundation. The author acknowledges the informative interview with the director AKTC (Syria) Dr. Ali Esmaiel and thanks to the Aga Khan Foundation for their inspiring project. The author also acknowledges the insightful comments of the anonymous reviewers and organizing committee for their help and efforts.

\section{REFERENCES}

Aga Khan Cultural Services (Syria), AKTC Management and Stuff, AKTC consultants, University of Venice (IUAV), Think City, Iconem, 2019. OLD CITY OF ALEPPO- Building Information and Preliminary Damage Assessment in three Pilot Conservation Areas. AKTC, Aleppo.

AKDN, 2018a. Historic Cities | Aga Khan Development Network [WWW Document]. Aga Khan Found. URL https://bit.ly/3e708Zz

AKDN, 2018b. Cultural development in Syria | Aga Khan Development Network [WWW Document]. SYRIA. URL https://bit.ly/379NgPH (accessed 6.6.20).

AKDN, 2018c. Syria | Aga Khan Development Network [WWW Document]. URL https://bit.ly/2XGakT0 (accessed 6.3.20).

Al-Din al-Asadi, K., 1984. Neighbourhoods and Souks of Aleppo.

Al-Ghazzi, 1992. Nahr al-Zahab fi TH. Dar al-Qalam al-Arabi Publications, Aleppo.

Al-Jibai, N., Shakeeb, C., 2016. Aleppo (Souqs) markets in the Ottoman era. Al Malweah Archaeol. Hist. Stud. 3, 53-72.

ALFA, S., 2015. Upgrading of Architectural Facades in Old Aleppo as an Introduction to Cultural Tourism Development.

Ali, C., 2016. Syrian Heritage under Threat. J. East. Mediterr. Archaeol. Herit. Stud. 1, 351-366.

DAI, 2019.3D MODELLING [WWW Document]. Ger. Archaeol. Inst. URL https://www.recover-urban-heritage.org/3d-modeling/
David, J.-C., Baker, F., Grandin, T., Hreitani, M., 1998. La Suwayqat 'Ali à Alep, La Suwayqat 'Ali à Alep. https://doi.org/10.4000/books.ifpo.7579

De Cesari, C., 2015. Post-colonial ruins. Anthropol. Today 31.

DGAM, 2017. First meeting of the Supreme National Steering Committee for the restoration of the Old City of Aleppo [WWW Document]. URL https://bit.ly/2BNAhrn (accessed 6.6.20).

Esmaiel, A., 2018. The Aga Khan Network and its projects within Syria in Mukhtar with Basil Mahrez [Interview] (19 2 2018).

Esmaiel, A., 2019. Director of the Aga Khan Foundation for Cultural Services in Syria [Interview] (21 07 2019).

Feilden, B.M., Jokilehto, J., 1998. Management Guidelines for World Heritage Sites.

Graham, S., 2009. Cities as battlespace: The new military urbanism. City 13, 383-402.

Grodach, C., 2002. Reconstituting identity and history in post-war Mostar, Bosnia-Herzegovina. City 6, 61-82.

ICOMOS, 2017. Post Trauma Recovery and Reconstruction for World Heritage and Cultural Properties 1-16.

Monreal, L., 2019. The opening ceremony of the Al-Saqqatiyya Souk in Old Aleppo [WWW Document]. Syrian Drama. URL https://bit.ly/2UlkgiI

Raymond, A., 1984. The Great Arab Cities in the 16th-18th centuries. New York Univ. Press.

Sabloff, J.A., 2008. Ancient Aleppo| Endangered Sites [WWW Document]. Archaeol. Matters. Left Coast Press.

Sim, D., 2016. Conflict [WWW Document]. Int. Bus. times. URL https://bit.ly/2UiqAY8 (accessed 5.18.20).

Stanley-Price, N. (editor), 2005. Cultural Heritage in Postwar Recovery. Papers from the ICCROM FORUM held on October 46, 2005, ICCROM Conservation Studies 6.

Syria Trust For Development [WWW Document], 2020. URL https://www.syriatrust.sy/en/news/37 (accessed 6.3.20).

Train, R.E., 2002. Remarks of the Honourable Russell E Train World Heritage Convention 30.

UNESCO/UNITAR, 2018. Five years of cnflict/ The State of Cultural Heritage in the Ancient City of Aleppo, UNESCO / UNITAR. UNESCO, Paris (France), Paris.

UNESCO, 2019. Ancient City of Aleppo - UNESCO World Heritage Centre [WWW Document]. UNESCO World Herit. Cent. 1992-2019. URL https://bit.ly/3cGJONl (accessed 11.20.19).

UNESCO, 2013. Emergency Red List of Syrian Antiquities at Risk is launched in New York [WWW Document]. UNESCO. URL https://bit.ly/378QLG0 (accessed 5.27.20).

UNESCO, 2010. The 1954 Hague Convention for the Protection of Cultural Property in the Event of Armed Conflict andits two (1954 and 1999) Protocols. 